\title{
Leaf foraging sources of leafcutter bees in a tropical environment: implications for conservation
}

\author{
Sneha S. Kambli ${ }^{1,2}$, M. S. Aiswarya ${ }^{3}$, K. ManoJ $^{1}$, Sangeetha Varma ${ }^{1}$, G. Asha ${ }^{1}$, \\ T. P. RAJESH ${ }^{1}$, Palatty Allesh SINU ${ }^{1,4}$ \\ ${ }^{1}$ Department of Animal Science, Central University of Kerala, Padannakad, PO 671314, Kerala, India \\ ${ }^{2}$ Department of Ecology and Environment, Pondicherry University, Pondicherry, India \\ ${ }^{3}$ Department of Biology, Indian Institute of Science Education and Research (IISER), Mohali, Punjab, India \\ ${ }^{4}$ Department of Ecology and Evolutionary Biology, University of Arizona, Tucson, AZ 85721, USA
}

Received 11 October 2016 - Accepted 28 December 2016

\begin{abstract}
Leafcutter bees collect leaf discs to encase brood cells. However, our understanding of their use of plants as nesting resources, which is critical for their conservation, is poor. We followed plants and observed bees cutting leaves to understand the leaf and plant traits of the leaf forage plants of Megachile spp. We studied whether the leaf size explains the cut size and the number of cuts in the leaves. The bees collected leaves from 59 species, 49 genera and 25 families of plants of various habits. Plant habit, leaf morphotype and leaf size did not influence leaf choice by the bees. Of the plants surveyed, $45.22 \%$ had the distinguishable cutting marks. About $63 \%$ and $98 \%$ of the plants the bees used are native to the region and to the tropical southern hemisphere, respectively. Bees selected leaves over an extreme size range, and the leaf size predicted the number of cuts on a leaf. Comparing our results with other studies, we conclude that the leafcutter bees' selection of plants is adapted to the local environment.
\end{abstract}

\section{Megachile / Megachilidae / leafcutter bee / urban ecosystem / pollinator}

\section{INTRODUCTION}

Bees, evolved from sphecoid wasps (Cardinal and Danforth 2013; Grimaldi 1999), have retained their ancestors' provisioning habit in nests (Radchenko and Pesenko 1996). However, they use plant matter, such as a blended pollen and nectar mixture (Michener 1964; Cane et al. 2011), rather than their ancestors' likely choice of animal matter (Evans 1971) as food for their developing larvae. They have also evolved the habit of lining the brood cells (Michener 1964).

Electronic supplementary material The online version of this article (doi:10.1007/s13592-016-0490-2) contains supplementary material, which is available to authorized users.

Corresponding author: P. A. Sinu, sinu@ cukerala.ac.in Manuscript editor: James Nieh
Ancestral sphecoid wasps nested in burrows in the soil and stored the larvae (the provision of the brood) there for many days to weeks in unlined brood cells (Kaltenpoth et al. 2005). Being hydrophilic in nature, the provision of bee hives is susceptible to early spoilage, particularly from infectious fungal molds (Müller et al. 1996; Messer 1985). Larvae are also vulnerable to predation and parasitism (Eltz et al. 2015; Krunić et al. 2005), so bees construct lined brood cells in the burrows in pre-existing cavities below and above ground to reduce predation risk (Eltz et al. 2015; Cane et al. 1983; Messer 1985). Most bees use a glandular secretion from Dufour's gland to line the brood cell (Williams et al. 1986; Hefetz 1987; Mitra 2013), but some species of bees have evolved the habit of using foreign materials, predominantly plant derivatives and soil particles, as their lining (MacIvor 2016; Litman et al. 2011; Cane et al. 1983; Messer 1985). 
Common examples of such species are the resinbees and the leafcutter bees belonging to the family Megachilidae. While the former collects plant resins to line cells, the latter collects whole leaves or leaf cuttings to line the brood cells (Wedmann et al. 2009; Litman et al. 2011; MacIvor 2016).

The family Megachilidae has ca. 3900 described species reported from all over the world, with 1478 of these species in the genus Megachile (Michener 2007). Some of these bees are the most important managed wild pollinators of several crop plants, especially the managed M. rotundata in North America (Pitts-Singer and Cane 2011; Bohart 1972; Kuriakose et al. 2009). Although we have some information on the nest biology of Megachile bees (Fischer 1951; Butler 1965; Strickler et al. 1996; MacIvor 2016), the information is sparse for such important specialist pollinators, and includes almost no information from the tropics. However, it is very likely that the abundance of the leaf plants is also an important factor in explaining the geographical distribution and local abundance of these bees. Therefore, knowledge about what the bees collect for their brood cell linings has direct implication in the conservation of leafcutter bees. In this paper, we report the leaf plants of leafcutter bees of peninsular India in a tropical village habitat. We studied whether leafcutter bees favored plants with particular growth habits or with particular leaf morphologies. We further studied whether the size of leaf cuts and number of cuts per leaf varied with the size of the leaves. Since the study took place in a village habitat, we studied what percent of the leaf plants were native to the region.

\section{MATERIALS AND METHODS}

\subsection{Study site and sampling}

The study was carried out in the North Malabar region of Kerala State in Peninsular India. The observations were made in six villages in adjoining the Nileshwar $\left(12^{\circ} 25.42^{\prime} \mathrm{N}, 75^{\circ} 11.896^{\prime} \mathrm{E}\right.$; elevation: $20 \mathrm{~m}$ asl) and Kanhangad $\left(12^{\circ} 28.740^{\prime} \mathrm{N}, 75^{\circ} 10.566^{\prime} \mathrm{E}\right.$; elevation: $24 \mathrm{~m}$ asl) municipalities of Kasaragod District. It is a semi-urban coastal plain area.

The study took place in the breeding season of Megachile spp between March and July in 2015 and
2016. In the sampling year 2015, we followed a random survey in different villages to identify the most common plants used by the bees (unpublished data). These data formed the basis of study site selection and an in-depth investigation in the sampling year 2016. The preliminary investigation in 2015 showed that a culturally-important native wild tree species Cassia fistula (Fabaceae; "golden shower"), which is grown in the yards of most houses in Kerala, was the most commonly cut plant species in the study area. C. fistula availability was therefore used as one criterion for selecting sampling sites in sampling year 2016, based on the prediction that $C$. fistula is an indicator species of Megachile spp. However, no sampling points stood less than $1 \mathrm{~km}$ from another. Using a focal C. fistula tree as a center point, all the plants including herbs, shrubs, vines and trees within a 100-sq-m area were thoroughly searched to identify leafcutter bee damage. Wherever a plant of the 59 species used by the bees was found in the sampling sites, replicated observations were made on that plant individual to understand what percent of the plants of a given species had cuts in the sampling year 2016. This brought out to a total of 1299 plants of 59 species in the total sample (Table I). During sampling, we directly observed Megachile disjuncta (F.), M. conjuncta Smith and M. fulvovestita Smith cutting leaves in many plants, but direct observations are not available for all the plant species. From our direct observations of $C$. fistula, we found that the cut sizes made by the bees varied substantially within species between their foraging cycles (20-70 cycles per day). Therefore, it is difficult to assign one particular size of cut to one species of bee. Hence, we used Megachile spp during the whole study. We presume that the leaf dimension is determined by the size of the cavity available at that given point of time (Horne 1995). We collected brood cells from some nest holes, and found that the cells are lined completely by leaves of only one particular species of plant (Figure 1). We identified all the leaf forage plants to family and species, and collected information on the habit of the plants (tree, shrub, herb, woody climber, vine) and the economic status of the plants (ornamental plant, avenue plant, weed, timber plant).

During our leaf cut surveys, we randomly selected individual plants that showed leafcutter bee damage to assess the characteristics of leaves used by the bees. Each leaf that showed damage was measured and assigned an age (young or old) based on the hardness of the leaves. Once the leaves were fully mature, and bees were unlikely to use them, 10-25 damaged leaves/species were collected. Bees normally begin their cuts on leaf margins, and do not 
Table I. Leaf sources of leafcutter bees of Megachile spp; percent of cut plants are not shown for the plant species having no replicated observations

\begin{tabular}{|c|c|c|c|c|c|c|}
\hline Family & Scientific name & Habit & $\begin{array}{l}\text { Leaf } \\
\text { texture }\end{array}$ & Nativity & $\begin{array}{l}n \\
\text { (plants) }\end{array}$ & $\begin{array}{l}\text { Percent plants } \\
\text { having cuts }\end{array}$ \\
\hline \multirow[t]{3}{*}{ Annonaceae } & Annona muricata & Tree & Glabrous & C. & 2 & 50 \\
\hline & Annona reticulata & Tree & Coriaceous & $\begin{array}{l}\text { C. } \\
\text { America }\end{array}$ & 19 & 42.11 \\
\hline & Polyalthia longifolia & Tree & Glabrous & Native & 27 & 3.70 \\
\hline Araceae & $\begin{array}{c}\text { Amorphophallus } \\
\text { paeoniifolius }\end{array}$ & Herb & Glabrous & Native & 51 & 9.80 \\
\hline Basellaceae & Basella alba & Vine & Succulent & Native & 1 & - \\
\hline \multirow[t]{2}{*}{ Combretaceae } & Combretum indicum & Vine & Rugose & Native & 25 & 8.00 \\
\hline & Getonia floribunda & Climber & Ciliate & Native & 2 & 100 \\
\hline Lamiaceae & Gmelina arborea & Tree & Glabrous & Native & 1 & - \\
\hline \multirow[t]{2}{*}{ Lauraceae } & Cinnamomum sp. & Tree & Glabrous & - & 16 & 68.75 \\
\hline & Persea americana & Tree & Glabrous & C. & 5 & 100 \\
\hline \multirow[t]{15}{*}{ Fabaceae } & $\begin{array}{c}\text { Adenanthera } \\
\text { pavonina }\end{array}$ & Tree & Glabrous & Native & 32 & 90.63 \\
\hline & Albizia saman & Tree & Glabrous & $\begin{array}{l}\text { C\&S. } \\
\text { America }\end{array}$ & 32 & 71.88 \\
\hline & Bauhinia acuminata & Shrub & Glabrous & SE Asia & 51 & 78.43 \\
\hline & Bauhinia tomentosa & Shrub & Glabrous & Native & 11 & 63.64 \\
\hline & $\begin{array}{l}\text { Caesalpinia } \\
\text { pulcherrima }\end{array}$ & Shrub & Glabrous & S. America & 16 & 100 \\
\hline & Cassia fistula & Tree & Glabrous & Native & 110 & 77.32 \\
\hline & $\begin{array}{r}\text { Centrosema } \\
\text { pubescens }\end{array}$ & Climber & Rugose & $\begin{array}{l}\text { C\&S. } \\
\text { America }\end{array}$ & 71 & 28.17 \\
\hline & $\begin{array}{l}\text { Desmodium } \\
\text { gangeticum }\end{array}$ & Herb & Glabrous & Native & 10 & 100 \\
\hline & Desmodium sp. & Climber & Glabrous & - & 1 & - \\
\hline & Erythrina variegata & Tree & Glabrous & Native & 1 & - \\
\hline & Gliricidia sepium & Shrub & Glabrous & $\begin{array}{l}\text { C. } \\
\text { America }\end{array}$ & 60 & 11.67 \\
\hline & Pongamia pinnata & Tree & Glabrous & Native & 18 & 55.56 \\
\hline & $\begin{array}{l}\text { Psophocarpus } \\
\text { tetragonolobus }\end{array}$ & Vine & Glabrous & $\begin{array}{l}\text { New } \\
\text { Guinea }\end{array}$ & 1 & - \\
\hline & $\begin{array}{l}\text { Cajanuss } \\
\text { carabaeoides }\end{array}$ & Climber & Glabrous & Native & 1 & - \\
\hline & Senna siamea & Tree & Glabrous & Native & 3 & 66.67 \\
\hline \multirow[t]{2}{*}{ Lythraceae } & $\begin{array}{l}\text { Lagerstroemia } \\
\text { speciosa }\end{array}$ & Tree & Glabrous & Native & 2 & 50 \\
\hline & Lawsonia inermis & Shrub & Glabrous & Native & 12 & 8.33 \\
\hline \multirow[t]{3}{*}{ Malvaceae } & $\begin{array}{l}\text { Hibiscus rosa- } \\
\text { sinensis } A\end{array}$ & Shrub & Glabrous & East Asia & 1 & - \\
\hline & $\begin{array}{l}\text { Hibiscus rosa- } \\
\text { sinensis } B\end{array}$ & Shrub & Glabrous & East Asia & 33 & 99.09 \\
\hline & $\begin{array}{l}\text { Hibiscus rosa- } \\
\text { sinensis } C\end{array}$ & Shrub & Glabrous & East Asia & 1 & - \\
\hline Meliaceae & Azadirachta indica & Tree & Glabrous & Native & 39 & 5.13 \\
\hline
\end{tabular}


Table I (continued)

\begin{tabular}{|c|c|c|c|c|c|c|}
\hline Family & Scientific name & Habit & $\begin{array}{l}\text { Leaf } \\
\text { texture }\end{array}$ & Nativity & $\begin{array}{l}n \\
\text { (plants) }\end{array}$ & $\begin{array}{l}\text { Percent plants } \\
\text { having cuts }\end{array}$ \\
\hline & Swietenia mahogani & Tree & Glabrous & $\begin{array}{l}\text { SE N. } \\
\text { America }\end{array}$ & 110 & 30.91 \\
\hline Menispermaceae & Anamirta cocculus & $\begin{array}{l}\text { Woody } \\
\text { Climber }\end{array}$ & Glabrous & Native & 1 & - \\
\hline \multirow[t]{2}{*}{ Myrtaceae } & Psidium guajava & Tree & Coriaceous & $\begin{array}{l}\text { C\&S. } \\
\text { Amerrica }\end{array}$ & 63 & 28.57 \\
\hline & $\begin{array}{l}\text { Syzygium } \\
\text { samarangense }\end{array}$ & Tree & Glabrous & SE. Asia & 9 & 22.22 \\
\hline \multirow[t]{2}{*}{ Nyctaginaceae } & Bougainvillea sp. & Vine & Glabrous & S. America & 52 & 11.54 \\
\hline & Pisonia alba & Shrub & Glabrous & Native & 11 & 100 \\
\hline \multirow[t]{2}{*}{ Oxalidaceae } & Averrhoa bilimbi & Tree & Ciliate & Native & 23 & 95.65 \\
\hline & Averrhoac arambola & Tree & Glabrous & Native & 14 & 64.29 \\
\hline \multirow[t]{7}{*}{ Phyllanthaceae } & Breynia sp. & Shrub & Glabrous & - & 6 & 50 \\
\hline & Breynia vitis-idaea & Shrub & Glabrous & Native & 27 & 33.33 \\
\hline & Bridelia stipularis & Climber & Ciliate & Native & 2 & 100 \\
\hline & Phyllanthus acidus & Tree & Glabrous & Native & 18 & 94.44 \\
\hline & $\begin{array}{l}\text { Phyllanthus } \\
\text { reticulatus }\end{array}$ & Shrub & Glabrous & Native & 29 & 10.34 \\
\hline & Phyllanthus sp. & Tree & Hirsute & - & 1 & - \\
\hline & Sauropus androgynus & Shrub & Glabrous & Native & 26 & 30.77 \\
\hline Piperaceae & Piper nigrum & Climber & Glabrous & Native & 31 & 12.90 \\
\hline Rhamnaceae & Ziziphus oenopolia & Climber & Scabrose & Native & 15 & 6.67 \\
\hline \multirow[t]{2}{*}{ Rosaceae } & Rosa sp A & Shrub & Glabrous & Native & 17 & 88.24 \\
\hline & Rosa sp B & Shrub & Glabrous & - & 17 & 47.06 \\
\hline \multirow[t]{2}{*}{ Rubiaceae } & Canthium sp. & Shrub & Glabrous & Native & 15 & 33.33 \\
\hline & Ixora sp. & Shrub & Glabrous & Native & 21 & 28.57 \\
\hline \multirow[t]{2}{*}{ Sapindaceae } & $\begin{array}{l}\text { Nephelium } \\
\text { lappaceum }\end{array}$ & Tree & Glabrous & SE. Asia & 36 & 75 \\
\hline & Dimocarpus longan & Tree & Glabrous & Native & 87 & 74 \\
\hline Sapotaceae & Mimusops elengi & Tree & Glabrous & Native & 1 & - \\
\hline Simaroubaceae & Simarouba amara & Tree & Glabrous & $\begin{array}{l}\text { C\&S. } \\
\text { America }\end{array}$ & 6 & 100 \\
\hline Verbenaceae & Duranta erecta & Shrub & Glabrous & $\begin{array}{l}\text { C\&S. } \\
\text { America }\end{array}$ & 1 & - \\
\hline \multirow[t]{2}{*}{ Vitaceae } & Cayratia trifolia & Vine & Glabrous & Native & 1 & - \\
\hline & Vitis vinifera & Climber & Floccose & SW. Asia & 3 & 66.67 \\
\hline
\end{tabular}

start cutting from previous damage even if the leaves are wide enough (Figure 1). We counted the number of cuts per leaf and measured the size of each cutting by plotting them on graph paper. The maximum length (the longitudinal measurement) and maximum width (perpendicular to the leaf axis) of the leaves and leaf cuts were measured using a centimeter ruler. Since our interest was to identify the shape of the leaf cuts rather than studying the leaf herbivory or defoliation, we used the length and width dimensions of the leaf cuts in our analyses rather than the leaf area. We then classified the leaves based on texture and nature as glabrous, ciliate, coriaceous, floccose, hirsute, rugose, scabrose or succulent. The shape of leaves and leaflets were classified as ovate, elliptical, cordate, linear, lobed/bilobed, rhomboid, lanceolate or palmate. We assessed the geographical origin of the plant species 

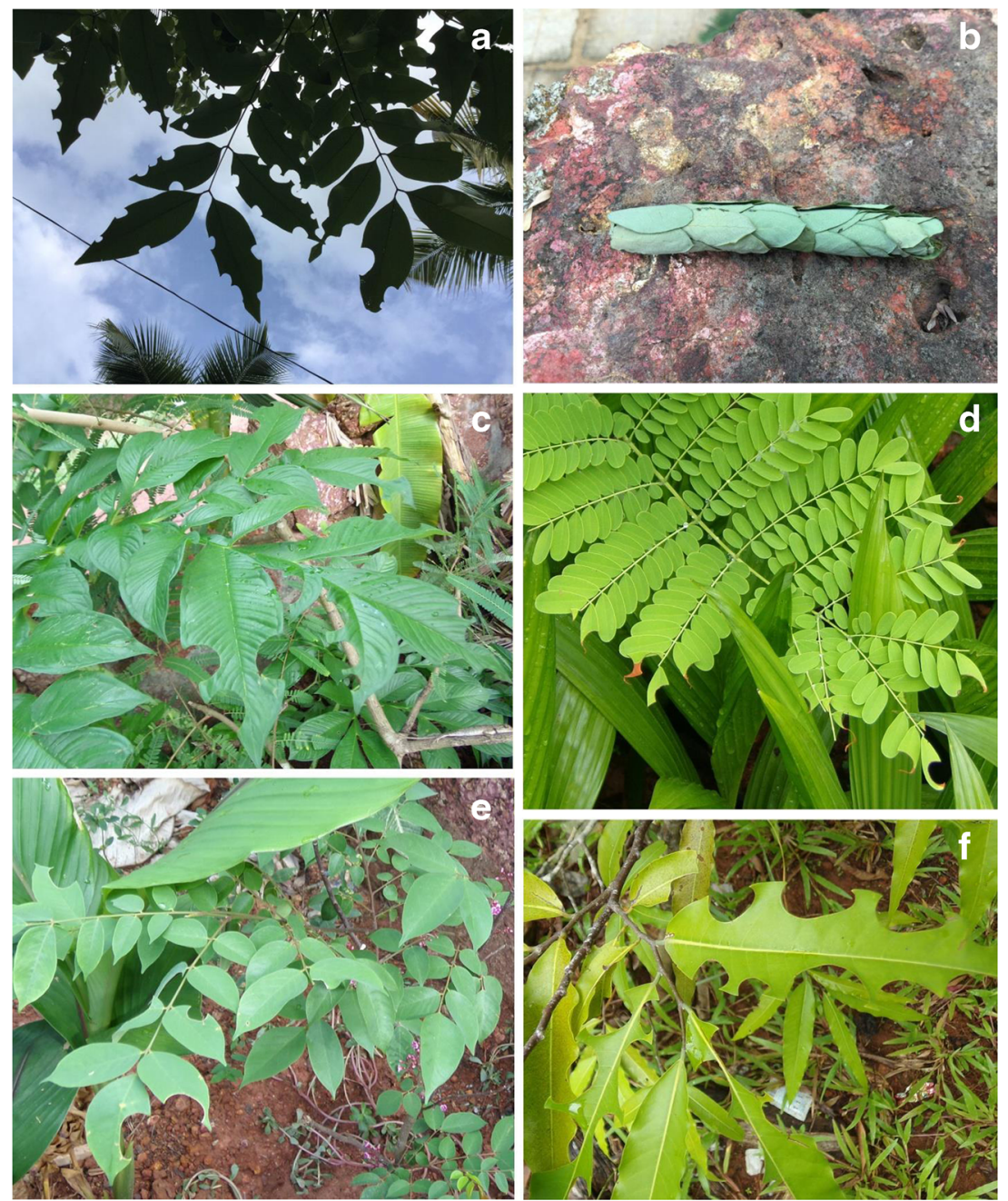

Figure 1. The distinguishable urn-shaped cuts of leafcutter bees on leaves of a Cassia fistula, c Amorphophallus paeoniifolius, d Caesalpina pulcherrima, e Averrhoa carambola, and $\mathbf{f}$ Polyalthia longifolia, and $\mathbf{b}$ a brood cell lined by the leaves of Caesalpina pulcherrima

using the species information pages of Kew Botanical Garden and encyclopedia of life (www.eol.org).

\subsection{Data analyses}

We plotted the dimensions (length and width) of the leaves and the leaf cuts made by the bees on each plant species using box plots to see the variation in the leaf dimensions within a species (Crawley 2007). We plotted the length and width dimensions of the leaves selected by the bees in a scatterplot to understand the kind of leaf types mostly used to make cuttings. We used linear mixed effect models using the "Ime" function in the "nlme" package to examine whether the leaf dimensions (leaf length and leaf width) and dimensions of leaf cuttings (cutting length and cutting width) varied between the plant species. We used a linear model using the " $1 \mathrm{~m}$ " function to examine the effect of leaf dimensions on the cutting dimensions. In order to understand whether the number of cuts in leaves is affected by the leaf size, we tested the significance of leaf dimensions using the generalized linear models using the "glm" function and poisson class of error distributions. We used a chisquare test to investigate whether the bees favored certain plant growth habits or morophotypes. All the analyses were performed in R 3.2.3 (R Core Team 2014). 


\section{RESULTS}

\subsection{Diversity of plants}

Megachile spp. collected leaves from 59 species of plants belong to 49 genera and 25 families, and from plants with many different growth habits (tree: 25 species; shrub: 18 species; climber including woody climber: 9 species; vines: 5 species; herb: 2 species) and leaf characteristics (Table I; Figure 1). The bees' preference for tree over other plant growth habits was significant $\left(X^{2}=29.07, P=0.000003\right)$. A total of $34(62.96 \%)$ species out of 54 species studied for their geographic origin were native to India or southern Asia (Table I). With the exception of Vitis vinifera and Swietenia mahagoni, all the other plants have geographical origins in tropical parts of the southern hemisphere in the old and new worlds. Irrespective of the habits and geographic origin, all plant species flushed new leaves during the study period, and the bees only cut young leaves. Forty-eight out of 59 species had glabrous leaves, and the remaining species had either ciliate (3 spp.), coriaceous (2 spp.), floccose (1 sp.), hirsute (1 sp.), rugose (2 spp.), scabrose (1 sp.) or succulent (1 sp.) leaves. The bees' preference for the glabrous leaves over the non-glabrous (glaucous) leaves was significant $\left(X^{2}=23.20, P=0.000001\right)$. The family Fabaceae contained the greatest number of species (15 spp.; 25.42\%) that the bees selected for the leaf cuttings, followed by Phyllanthaceae (7 spp.). About $68 \%$ of the plants selected by the bees in this study are cultivated ornamental or medicinal plants.

Of 1299 plants from the 59 species which were used by the bees, $45.22 \%$ of the plants had leaf cuts. Fabaceae contained the greatest number of species (15 spp.; 42\%) used by the bees followed by Phyllanthaceae ( $7 \mathrm{spp}$.). The frequency of plants that showed leafcutter bee damage ranged between 3.70 and $100 \%$ per species with an average of $61.58 \%$ per species. Table I provides the details of the plant species and the frequency of cut plants per species.

\subsection{Morphology and dimension of leaves and leaf cuttings}

The leaf plants of leafcutter bees were dominated by plants with ovate leaves $(44.83 \%)$, followed plants with elliptical leaves (20.69\%) and the plants with other types of leaves (cordate $(10.34 \%)$, linear $(6.9 \%)$, lobed/bilobed $(5.17 \%)$, rhomboid $(5.17 \%)$, lanceolate $(3.45 \%)$, palmate $(1.72 \%)$ ). Leafcutter bees used ovate leaved plants significantly more often than plants with other leaf shapes $\left(X^{2}=16.33, P=0.00005\right)$.

The average length $(8.68 \pm 0.30(\mathrm{SE}) \mathrm{cm}$, range $\left.=1.6-29.00 \mathrm{~cm} ; t_{349}=13.77, P=0.000\right)$ and average width $(4.62 \pm 0.21 \mathrm{~cm}$, range $=1-$ $\left.24.6 \mathrm{~cm} ; t_{349}=10.61, P=0.0000\right)$ of the leaves used by the bees to cut leaf discs varied significantly among the plant species (Online Resource, Fig. S1). The length and the width of the leaves used by the bees were positively correlated $\left(R^{2}=\right.$ 0.52; One-Way ANOVA: $\mathrm{F}_{1,640}=703.6, P=$ 0.0000 ), suggesting that the bees used the ovoid shaped leaves better than the linear kind of leaves (Online Resource, Fig. S2). The average length $\left(1.89 \pm 0.03\right.$ (s.e.) $\mathrm{cm}$; range $=0.6-5.1 \mathrm{~cm} ; t_{349}=$ $33.18, P=0.000)$ and average width $(1.11 \pm 0.11$ $\mathrm{cm}$; range $=0.3-3.2 \mathrm{~cm} ; t_{349}=34.66, P=$ 0.0000 ) of the leaf cuttings were also significantly different between the plant species (Online Resource, Fig. S3). The scatterplot showed that the width of the cuttings was increasing with the length of the cuttings $\left(R^{2}=0.56\right.$, one-way ANOVA: $\left.F_{1,640}=829, P=0.0000\right)$ (Figure 2). Interestingly, length of the leaves predicted a small amount of the variation in the length $\left(R^{2}=0.009\right.$, one-way ANOVA: $F_{1,640}=6.304$, $P=0.01)$ and width $\left(R^{2}=0.03\right.$, one-way ANOVA: $\left.\mathrm{F}_{1,620}=19.08, P=0.00001\right)$ of the leaf cuttings (Figure 3 ), but width of the leaves did not explain any variation in the leaf cutting dimensions (Online Resource, Fig. S4). An average of 2.28 cuts $( \pm 0.13$, range $=1-18 ; n=270$ leaves $)$ were counted per leaf. As expected, the number of cuts significantly increased with the length $(z=$ $11.410, P=0.0000)$ and width $(z=11.996, P=$ 0.0000 ) of the leaves (Figure 4).

\section{DISCUSSION}

The overall aim of this study was to identify and understand the leaf and plant traits of the leaf foraging plants used by the leafcutter bees of Megachile spp. to line their brood cells. We found that the bees collect leaves from 59 species of plants of various 


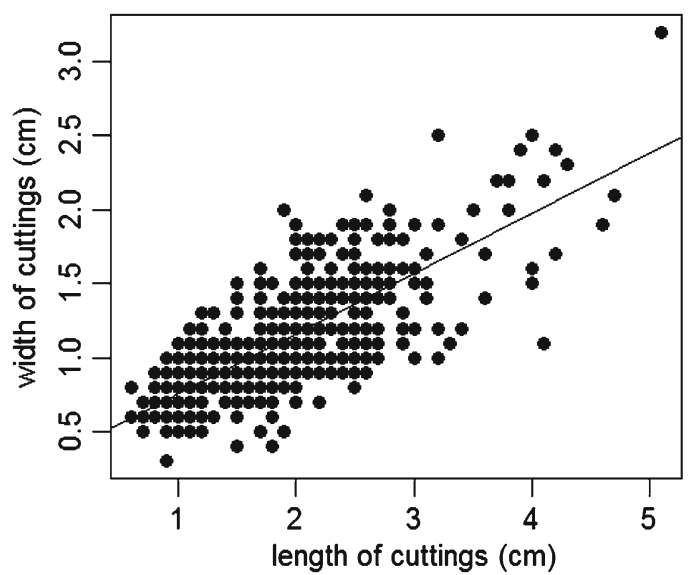

Figure 2. The relationship between the length and width of the leaf cuttings

habits, leaf morphotypes, and leaf sizes, indicating that none of these physical attributes of the plants limit the selection of plants by the leafcutter bees. The list of species is dominated by the members of Fabaceae, which concurs with the observations made by other studies in the northern hemisphere (MacIvor 2016; Butler 1965; Hobbs 1956; Hobbs and Lilly 1954; Fischer 1951). However, only one other study (MacIvor 2016) has made serious efforts to investigate the diversity of leaf-foraging plants of leafcutter bees. We surveyed plants to investigate which ones the bees used as nesting resources, while MacIvor (2016) collected leaves from the trap nests and used DNA barcode techniques to identify the plants used by the bees in Canada. The results of both the studies are highly comparable; the number of species ( 59 vs. $54 ; X^{2}=$ $0.14, P=0.70$ ), genera (51 vs. $46 ; X^{2}=0.16, P=$ 0.68 ) and families ( 23 vs. $24 ; X^{2}=0.02 ; P=0.88$ )
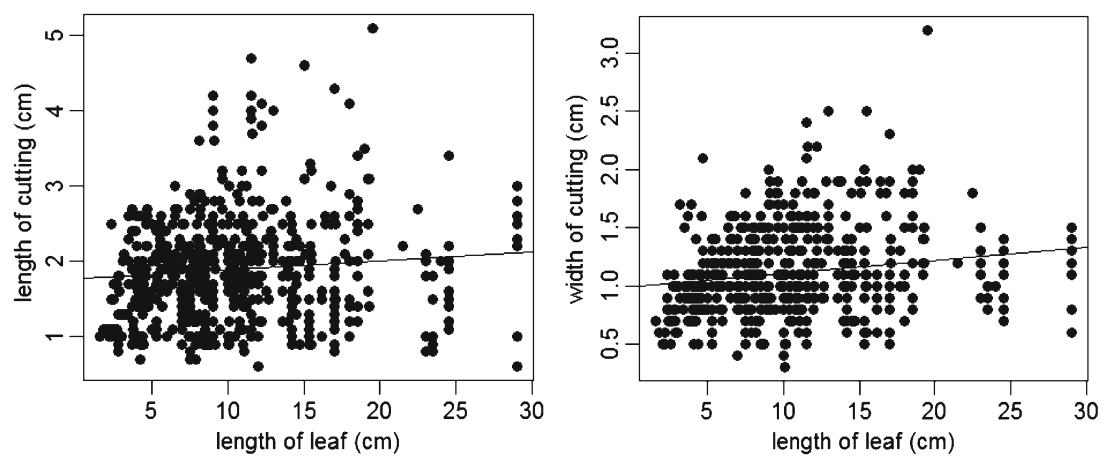

Figure 3. The relationships between the length of the leaves with the length and width of the leaf cuttings 

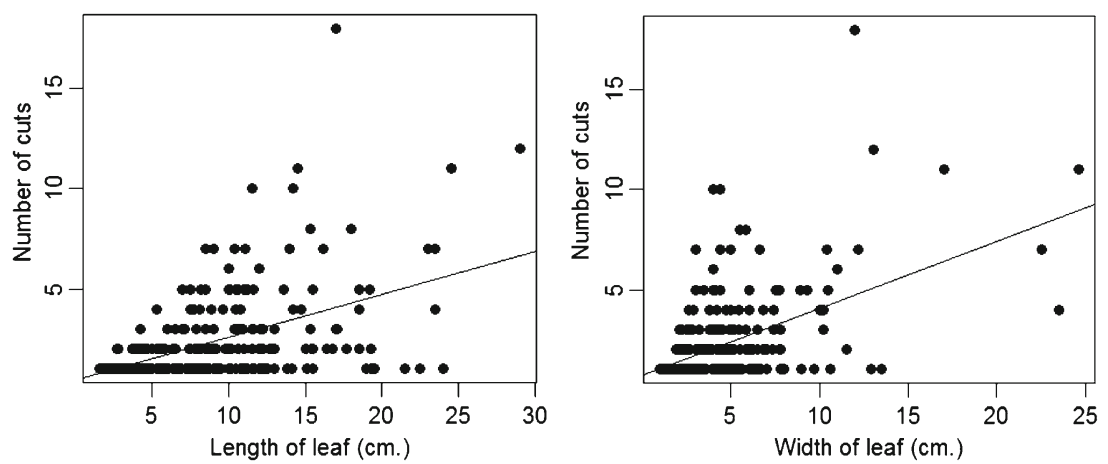

Figure 4. The relationships of length and width of the leaves with the number of cuts in leaves

pressure on a plant as reported by Nugent and Wagner (1995), except for very young saplings. The toughness of the hard midrib and veins of older leaves might prevent the bees from using them (Horne 1995). Except in the terminal part of the young leaves, the bees rarely make a cutting through the midbrib part of even the younger leaves.

The study found that the bees selected small (1.6 $\mathrm{cm}$ long by $1 \mathrm{~cm}$ wide) to large leaves $(29 \mathrm{~cm}$ long by $24.6 \mathrm{~cm}$ wide) with an average of $8.68 \mathrm{~cm}$ long and $4.62 \mathrm{~cm}$ wide leaves. Therefore, it is unlikely that the leaf size is a very important criterion for the selection of plants as suggested by some previous studies (Horne 1995; Eigenbrode et al. 1999). We found that the size of leaves varied greatly within and among plant species. Interestingly, neither the length nor the width of the leaf explained much of the variation in size of leaf cuts, which seems to be independent of the size of the leaves. However, leaf size did predict the number of cuttings on the leaves (Eigenbrode et al. 1999). From our observations on $C$. fistula (one of the largest-leaved species), a leafcutter bee makes several trips between the nesting site and a given leaf for cuttings until the leaf margin is completely used (Figure 1). On many occasions, the same bee made cuts of different dimensions during its cycle of visits. On one occasion, an individual of $M$. disjuncta made 64 trips between a rose plant and its nest hole (distance $=0.5 \mathrm{~m}$ ) between 0800 and 0830 hours . All three bee species that we encountered in this study are native to India, and are similar in body size. We have direct observations that a single bee made cuts of different dimensions in large leaves (e.g. C. fistula) and that the small leaves received cuts of similar size to those in the large leaves. This indicates that cut size is not specific to a given bee species, but might be determined by the size of the cavity available for nesting. Moreover, MacIvor (2016) also reported a greater overlap in the leaf resources used by the three bee species of his choice in Canada.

A possible explanation for the abundance of glabrous and ovate leafy plants in the leaf source of leafcutter bees may be that such plants are abundant in the habitat. However, this needs to be further investigated. Since the purpose of leaflining brood cells is to limit fungal invasion into the provisions (Eltz et al. 2015; Messer 1985), comparative analyses of the leaf phytochemicals of the plants that are selected and not selected by the bees might enrich our knowledge on the leaf preference of leafcutter bees. Most of the Fabaceae and Rosaceae plants have large quantities of antimicrobial tannins and flavanoids (Borchardt et al. 2008; Nickell 1959), which might explain why these species are frequently used as leaf sources across continents (MacIvor 2016).

Our study agrees with MacIvor (2016) that leafcutter bees make use of a greater diversity of plants of different habits and leaves of different morphotypes for leaf cuttings to line brood cells than previously documented (Hobbs and Lilly 1954; Butler 1965). However, few in-depth investigations on the leaf preference of leafcutter bees are available in the literature. To our surprise, all the studies on the leaf preference of leafcutter bees are reported from urban (MacIvor 2016) or agricultural environments (Hobbs and Lilly 1954; Butler 1965). This would 
probably explain the high proportion of native and exotic ornamental and crop plants in the list of leaf plants of leafcutter bees. This gives opportunities and challenges for the conservation of leafcutter bees. Ornamental plants are integral part of urban parks and households, which offer both pollen and nectar to the bees, and are known to support a high diversity of bees (Fortel et al. 2014; Garbuzov and Ratnieks 2014). A careful selection of ornamental plants could sustain populations of leafcutter bees. This information would be helpful for landscape planners and agriculturists while selecting plants for greenscaping the urban ecosystems (Threlfall et al. 2015) and establishing a suitable agrienvironmental scheme (Potts et al. 2005). On the other hand, we do not know what plants the leafcutter bees use for nest lining in native habitats, such as forests and grasslands, particularly in tropical areas (Raw 2004). Interestingly, the ecology of this important pollinator and its plant-herbivore interactions are poorly represented in the literature.

\section{ACKNOWLEDGEMENTS}

SK would like to thank the Indian Academy of Sciences, Bangalore, for a summer research fellowship. SV and GA would like to thank the KSCSTE for the PhD fellowship. The work was supported by a Conservation Research and Exploration grant by National Geographic Society, Washington DC and Young Scientist grant by Science Engineering Research Board, Department of Science and Technology, New Delhi to PAS. We also thank Giby Kuriakose (Sacred Heart College, Thevara) and Jobiraj T. (Kodenchery College, Kozhikode) for identifying the plant species and the bee species, respectively. We thank Judith Bronstein, Kelsey Yule and Gordon Smith for their comments on the MS.

Contributions SK,AS,KM,SV,TPR did field work, GA did molecular work, PAS did analysis and write MS

Sources de I'approvisionnement en feuilles des abeilles coupeuses de feuilles dans un environnement tropical : implications concernant leur conservation

Megachile / Megachilidae / écosystème urbain / pollinisateur / Inde / région tropicale
Blatt -foragier Quellen von Blattschneiderbienen in einer tropischen Umwelt: Konsequenzen für den Naturschutz

\section{Megachile / Megachilidae / Stadtökosystem /Bestäuber / Indien / Tropische Umgebung}

\section{REFERENCES}

Bohart, G.E. (1972) Pollination of alfalfa and the red clover. Annu. Rev. Entomol. 2, 355-380

Borchardt, J., Wyse, D., Sheaffer, C. (2008) Antimicrobial activity of native and naturalized plants of Minnesota and Wisconsin. J. Med. Plants Res. 2, 98-110

Butler, G.B. (1965) Distribution and host plants of leafcutter bees in Arizona. Arizona Agricultural Experiment Station Bulletin. 167.

Cane, J.H., Gardner, D.R., Harrison, P.A. (2011) Nectar and pollen sugars constituting larval provisions of the alfalfa leaf-cutting bee (Megachile rotundata) (Hymenoptera: Apiformes: Megachilidae). Apidologie 42, 401-408

Cane, J.H., Gerdin, S., Wife, G. (1983) Mandibular gland secretions of solitary bees (Hymenoptera: Apoidea): potential for nest cell disinfection. J. Kans. Entomol. Soc. 56, 199-204

Cardinal, S., Danforth, B.N. (2013) Bees diversified in the age of eudicots. Proc. R. Soc. B. 280, 20122686

Crawley, M.J. (2007) The R Book. Wiley, London

Eigenbrode, S.D., White, M., Tipton, J.L. (1999) Differential Cutting by Leaf-Cutter Bees (Megachilidae: Hymenoptera) on Leaves of Redbud (Cercis canadensis) and Mexican Redbuds (Cercis canadensis var. mexicana) with Different Surface Waxes. J. Kans. Entomol. Soc. 72, 73-81

Eltz, T., Küttner, J., Lunau, K. (2015) Plant secretions prevent wasp parasitism in nests of wool-carder bees, with implications for the diversification of nesting materials in Megachilidae. Front. Ecol. Evol. 2, 86

Evans, H. (1971) Observations on the nesting behavior of wasps of the tribe Cercerini. J. Kans. Entomol. Soc. 44, 500-523

Fischer, R.L. (1951) Observations on the nesting habits of Megachilid bees. J. Kans. Entomol. Soc. 24, 46-50

Fortel, L., Henry, M., Guilbaud, L., Guirao, A., Kuhlmann, M. (2014) Decreasing abundance, increasing diversity and changing structure of the wild bee community (Hymenoptera: Anthophila) along an urbanization gradient. PLoS ONE 9, e104679

Garbuzov, M., Ratnieks, F. (2014) Listmania: the strengths and weaknesses of lists of garden plants to help pollinators. Bioscience 64, 1019-1026

Grimaldi, D. (1999) The co-radiations of pollinating insects and angiosperms in the Cretaceous. Ann. Mo. Bot. Gard. 86, 373-406 
Hefetz, A. (1987) The role of Dufour's gland secretions in bees. Physiol. Entomol. 12, 243-253

Hobbs, G.A. (1956) Ecology of the leaf-cutter bee Megachile perihirta Ckll. (Hymenoptera: Megachilidae) in relation to production of alfalfa seed. Can. Entomol. 88, 625-631

Hobbs, G.A., Lilly, C.E. (1954) Ecology of species of Megachile Latreille in the mixed prairie Region of Southern Alberta with special reference to pollination of Alfalfa. Ecology 35, 453-462

Horne, M. (1995) Leaf area and toughness: effects on nesting material preferences of Megachile rotundata (Hymenoptera: Megachilidae). Ann. Entomol. Soc. Am. 88, 868-875

Kaltenpoth, M., Göttler, W., Herzner, G., Strohm, E. (2005) Symbiotic bacteria protect wasp larvae from fungal infestation. Curr. Biol. 15, 475-479

Krunić, M., Stanisavljević, L., Pinzauti, M. (2005) The accompanying fauna of Osmia cornuta and Osmia rufa and effective measures of protection. Bull. Insectol. 58, 141-152

Kuriakose, G., Sinu, P.A., Shivanna, K.R. (2009) Domestication of cardamom (Elettaria cardamomum) in Western Ghats, India: divergence in productive traits and a shift in major pollinators. Ann. Bot. 103, 727-733

Litman, J.R., Danforth, B.N., Eardley, C.D., Praz, C.J. (2011) Why do leafcutter bees cut leaves? New insights into the early evolution of bees. Proc. R. Soc. Lond. B 278, 3593-3600

MacIvor, J.S. (2016) DNA barcoding to identify leaf preference of leafcutting bees. R Soc. Open Sci. 3, 150623

Messer, A. (1985) Fresh dipterocarp resins gathered by megachilid bees inhibit growth of pollen-associated fungi. Biotropica 17, 175-176

Michener, C.D. (2007) The bees of the world, 2nd edn. Johns Hopkins University Press, Baltimore

Michener, C.D. (1964) Evolution of the nests of bees. Am. Zool. 4, 227-239

Mitra, A. (2013) Function of the Dufour's gland in solitary and social Hymenoptera. J. Hymenopt. Res. 35, 33-58

Müller, A., Topfl, W., Amiet, F. (1996) Collection of extrafloral trichome secretions for nest wool impregnation in the solitary bee Anthidium manicatum. Naturwissenschaften 83, 230-232
Nickell, L. (1959) Antimicrobial activity of vascular plants. Econ. Bot. 13 , 281-318

Nugent, S.P., Wagner, M.R. (1995) Clone and leaf position effects on populus defoliation by leaf-cutting bees (Hymenoptera: Megachilidae). For. Ecol. Manag. 77, 191-199

Pitts-Singer, T., Cane, J. (2011) The Alfalfa Leafcutting Bee, Megachile rotundata: the World's Most Intensively Managed Solitary Bee. Annu. Rev. Entomol. 56, 221-237

Potts, S., Vulliamy, B., Roberts, S., O’Toole, C. (2005) Role of nesting resources in organising diverse bee communities in a Mediterranean landscape. Ecol. Entomol. 30, 78-85

Radchenko, V.G., Pesenko, Y.A. (1996) "Proto-bee" and its nests: a new hypothesis concerning the early evolution of Apoidea (Hymenoptera). Entomol. Revis. 75, 140162

Core Team, R. (2014) R: A language and environment for statistical computing. R Foundation for statistical computing, Vienna, Austria. http://www.R-project.org

Raw, A. (2004) Leafcutter and mason bees: a biological catalogue of the genus Megachile of the Neotropics. http://www.webbee.org.br/raw/catalogue (accessed on 17 June 2016)

Strickler, K., Scott, V.L., Fischer, R.L. (1996) Comparative nesting ecology of two sympatric leafcutting bees that differ in body size (Hymenoptera: Megachilidae). J. Kans. Entomol. Soc. 69, 26-44

Threlfall, C., Walker, K., Williams, N., Hahs, A. (2015) The conservation value of urban green space habitats for Australian native bee communities. Biol. Conserv. 187, 240-248

Wedmann, S., Wappler, T., Engel, M. S. (2009) Direct and indirect fossil records of megachilid bees from the Paleogene of Central Europe (Hymenoptera: Megachilidae). Naturwissenschaften 96, 703-712

Williams, H. J., M. R. Strand, G. W. Elzen, and S. B. Vinson.(1986) Nesting behavior, nest architecture, and use of DufourÕsgland lipids in nest provisioning by Megachile integra and M. mendica mendica (Hymenoptera: Megachilidae).J. Kans. Entomol. Soc. 59, 588-597 